\title{
Influences of habitat type and environmental variables on benthic macroinvertebrate communities in a large shallow subtropical lake (Lake Taihu, China)
}

\author{
Yongjiu Cai $^{1,2}$, Zhijun Gong ${ }^{1 *}$ and Boqiang Qin ${ }^{1}$ \\ 1 Taihu Lake Laboratory Ecosystem Research Station, State Key Laboratory of Lake Science and Environment, Nanjing Institute \\ of Geography and Limnology, Chinese Academy of Sciences, 73 East Beijing Road, 210008 Nanjing, P.R. China \\ ${ }^{2}$ Graduate University of Chinese Academy of Sciences, 100049 Beijing, P.R. China
}

Received 19 July 2010; Accepted 28 September 2010

\begin{abstract}
We investigated benthic macroinvertebrate communities in three contrasting habitats of a large shallow lake from February to November 2009. The three habitats differed markedly in their environmental characteristics (e.g., trophic status, substrate type, wind exposure). A total of 36 species were collected from the three habitats. The calculated descriptors (abundance, biomass and Pielou evenness index) differed significantly among the habitats. Generally, Tubificidae, Bivalvia and Gastropoda dominated the benthic community in abundance and biomass, but they varied greatly in abundance among the habitats. Analysis of similarities (ANOSIM) and non-metric multidimensional scaling (NMDS) analyses revealed significantly different macroinvertebrate assemblages among the habitats. North Bays had the lowest biodiversity and were exclusively dominated by pollution-tolerant species (e.g., Limnodrilus hoffmeisteri and Rhyacodrilus sinicus). Communities in the open lake contained intermediate biodiversity and were characterized by five species belonging to several taxonomic groups (e.g., Corbicula fluminea, L. hoffmeisteri and Gammarus sp.). Macrophyte-dominated habitats (East Bays) presented the highest diversity and evenness and were mainly characterized by gastropods. A canonical correspondence analysis (CCA) demonstrated that habitat-specific differences in trophic status, pollution level, wind-induced disturbance and macrophyte distributions were highly correlated with macroinvertebrate community structure.
\end{abstract}

Key words: Tubificidae / Mollusca / Gastropoda / eutrophication / wind-induced disturbance / canonical correspondence analysis (CCA)

\section{Introduction}

A lack of a long period thermal stratification is the most typical feature for shallow lakes, which increases the water-sediment interaction and facilitates the influence of biotic and abiotic factors at the water-sediment interface (Scheffer, 1998). Benthic invertebrates play important roles in the water-sediment processes in shallow lakes. They change the physical-chemical parameters of sediments (Vaughn and Hakenkamp, 2001) and promote nutrient cycling and energy flows (Covich et al., 1999; Vanni, 2002). They are also important in linking the benthic and pelagic food-webs (Palmer et al., 2000). However, as documented by Havens et al. (2007), shallow lakes are often located in lowland regions that are significantly affected by anthropogenic activities. These

\footnotetext{
*Corresponding author: zjgong@niglas.ac.cn
}

lakes often endure severe environmental deterioration, such as eutrophication, metal and POPs pollution (Wang et al., 2003; Smith et al., 2006; Wu et al., 2010), decreasing biodiversity and ecosystem services (Dudgeon et al., 2005). Recent studies have found that extinction rates of freshwater fauna to be as much as five times greater than those of terrestrial fauna (Ricciardi and Rasmussen, 1999). Impairment of aquatic resources also has substantial negative ecological effects on the diversity, abundance, biomass and structure of macroinvertebrate assemblages (Strayer, 2006).

Therefore, understanding the underlying mechanisms that drive community structure and diversity of lake benthic macroinvertebrates is paramount if we are to better understand diversity loss and to restore diversity in these degraded lake ecosystems. Previous studies have reported several factors that influenced benthic macroinvertebrate communities. These studies suggested that 
Table 1. Physicochemical and biological parameters for the three habitats in Lake Taihu (standard deviation are given in parentheses). When ANOVA indicated significant differences between the habitats, each habitat differing in the post hoc Tukey tests was given a different letter ( $\mathrm{a}, \mathrm{b}$ or $\mathrm{c}, P<0.05$ ). Trophic status was assessed using mean $\mathrm{Chl} a$ by the fixed boundary classification system for lake trophic status accepted by OECD (1982).

\begin{tabular}{|c|c|c|c|c|c|}
\hline Parameter & Code & North Bays & Open Lake & East Bays & $P$ value \\
\hline Water depth (m) & Depth & $2.53(0.23)^{\mathrm{a}}$ & $2.8(0.25)^{\mathrm{ab}}$ & $1.8(0.25)^{\mathrm{b}}$ & 0.046 \\
\hline Water temperature $\left({ }^{\circ} \mathrm{C}\right)$ & WT & $17.24(0.38)$ & $16.76(0.39)$ & $17.13(0.33)$ & 0.174 \\
\hline Secchi depth $(\mathrm{cm})$ & SD & $31.4(6.9)^{\mathrm{b}}$ & $21.0(3.0)^{\mathrm{b}}$ & $70.0(23.1)^{\mathrm{a}}$ & $<0.001$ \\
\hline $\mathrm{pH}$ & $\mathrm{pH}$ & $8.1(0.22)$ & $8.1(0.04)$ & $8.15(0.11)$ & 0.792 \\
\hline Total suspended solids (mg.L ${ }^{-1}$ ) & TSS & $52.56(18.93)^{\mathrm{b}}$ & $103.43(26.36)^{\mathrm{a}}$ & $40.65(17.14)^{\mathrm{b}}$ & 0.002 \\
\hline Conductivity $\left(\mu \mathrm{s} . \mathrm{cm}^{-1}\right)$ & Cond & $552.3(39.2)^{\mathrm{a}}$ & $475.2(44.2)^{\mathrm{b}}$ & $475.9(12.9)^{\mathrm{b}}$ & 0.003 \\
\hline Dissolved oxygen $\left(\mathrm{mg} \mathrm{L}^{-1}\right)$ & $\mathrm{DO}$ & $8.56(1.18)$ & $9.19(0.14)$ & $9.24(0.40)$ & 0.224 \\
\hline Chemical oxygen demand (mg. $\left.\mathrm{L}^{-1}\right)$ & $\mathrm{COD}_{\mathrm{Mn}}$ & $5.23(0.55)^{\mathrm{a}}$ & $4.11(0.24)^{\mathrm{b}}$ & $3.87(0.67)^{\mathrm{b}}$ & 0.001 \\
\hline Biochemical oxygen demand (mg.L $\left.\mathrm{L}^{-1}\right)$ & $\mathrm{BOD}_{5}$ & $3.28(1.57)^{\mathrm{a}}$ & $1.24(0.19)^{\mathrm{b}}$ & $1.04(0.45)^{\mathrm{b}}$ & $<0.001$ \\
\hline Ammonium (mg.L $\left.\mathrm{L}^{-1}\right)$ & $\mathrm{NH}_{4}-\mathrm{N}$ & $1.05(0.85)$ & $0.51(0.13)$ & $0.39(0.08)$ & 0.060 \\
\hline Nitrite $\left(\mathrm{mg} . \mathrm{L}^{-1}\right)$ & $\mathrm{NO}_{2}-\mathrm{N}$ & $0.071(0.037)^{\mathrm{a}}$ & $0.022(0.018)^{b}$ & $0.009(0.004)^{b}$ & 0.001 \\
\hline Nitrate $\left(\mathrm{mg} . \mathrm{L}^{-1}\right)$ & $\mathrm{NO}_{3}-\mathrm{N}$ & $0.99(0.26)^{\mathrm{a}}$ & $0.84(0.15)^{\mathrm{a}}$ & $0.33(0.09)^{\mathrm{b}}$ & $<0.001$ \\
\hline Total nitrogen (mg. $\left.\mathrm{L}^{-1}\right)$ & TN & $3.79(1.19)^{\mathrm{a}}$ & $2.65(0.11)^{\mathrm{b}}$ & $1.46(0.2)^{\mathrm{c}}$ & $<0.001$ \\
\hline Orthophosphate (mg.L ${ }^{-1}$ ) & $\mathrm{PO}_{4}-\mathrm{P}$ & $0.031(0.023)^{\mathrm{a}}$ & $0.013(0.002)^{\mathrm{ab}}$ & $0.007(0.002)^{b}$ & 0.023 \\
\hline Total phosphorus (mg. $\mathrm{L}^{-1}$ ) & $\mathrm{TP}$ & $0.17(0.08)^{\mathrm{a}}$ & $0.1(0.01)^{\mathrm{ab}}$ & $0.06(0.02)^{\mathrm{b}}$ & 0.003 \\
\hline Chlorophyll $a\left(\mu \mathrm{g} . \mathrm{L}^{-1}\right)$ & Chl $a$ & $23.12(5.51)^{\mathrm{a}}$ & $9.66(3.78)^{\mathrm{b}}$ & $7.22(5.99)^{\mathrm{b}}$ & $<0.001$ \\
\hline Total nitrogen in surficial sediment $\left(\mu \mathrm{g} . \mathrm{g}^{-1}\right)$ & TPs & $1597.3(372.5)$ & $1144.6(169.6)$ & $1593.4(453.6)$ & 0.056 \\
\hline Total phosphorus surficial sediment $\left(\mu \mathrm{g} . \mathrm{g}^{-1}\right)$ & TNs & $599.26(541.47)$ & $276.88(32.54)$ & $330.6(63.38)$ & 0.093 \\
\hline Oxidation-reduction potential $(\mathrm{mV})$ & ORP & $-219(72)^{\mathrm{b}}$ & $-9.5(79)^{\mathrm{a}}$ & $-190(144)^{\mathrm{b}}$ & 0.007 \\
\hline Aquatic macrophytes (percent cover) & & 0 & 0 & $75 \%$ & \\
\hline Substrate type & & mud & muddy sand & mud and detritus & \\
\hline Trophic status & & eutrophic-hypertrophic & eutrophic & mesotrophic-eutrophic & \\
\hline
\end{tabular}

variability in physical factors (e.g., water depth, grain size, habitat complexity and wind exposure) (Sauter and Güde, 1996; Shostell and Williams, 2007; Bazzanti et al., 2009), chemical factors (e.g., nutrients in water and sediment, dissolved oxygen and pH) (Free et al., 2009), and biological factors (e.g., fish predation, macrophytes) (Céréghino et al., 2008) significantly affect the benthic community.

Several studies have attempted to relate the benthic community to habitat conditions in shallow lakes, and most of these studies were conducted based on comparisons of several small lakes (Żbikowski and Kobak, 2007). Some undetected factors, however, may also significantly affect the benthic community. Large shallow lakes often possess significant geographical environmental gradients (e.g., trophic status) and different habitats (e.g., phytoplanktonand macrophyte-dominant regions) (Scheffer, 1998), which provide good opportunities for revealing the factors that regulate benthic community structure.

In the present study, we investigated benthic macroinvertebrate communities in a large shallow eutrophic lake, Lake Taihu. It is the third largest freshwater lake in China, located in the southern Changjiang (Yangtze) River Delta, which is one of the most densely populated regions in China (Qin et al., 2007). The lake is important for aquaculture, tourism and recreation, shipping, and is a drinking water source for several cities, including Shanghai, Suzhou, Wuxi and Huzhou (Qin, 2008). In the past 30 years, the lake has undergone serious deterioration as a result of a high degree of economic development and urbanization, and Microcystis spp. blooms have occurred each summer and have extended progressively south from the northern bays of the lake. In recent years, more attention has been given to the aquatic biological community in this lake (e.g., phytoplankton, zooplankton and microorganisms) (Chen et al., 2003; Ke et al., 2008; Tang et al., 2010). However, the benthic macroinvertebrate community and its possible regulating factors were underevaluated. The objectives of this work were to analyze the community structure of benthic macroinvertebrates in different habitats of Lake Taihu and to discuss the factors regulating their structure, diversity and distribution.

\section{Methods}

\section{Study site description}

Lake Taihu $\left(30^{\circ} 55^{\prime} 40^{\prime \prime}-31^{\circ} 32^{\prime} 58^{\prime \prime} \mathrm{N}\right.$ and $119^{\circ} 52^{\prime} 32^{\prime \prime}-$ $\left.120^{\circ} 36^{\prime} 10^{\prime \prime} \mathrm{E}\right)$ has an area of $2338 \mathrm{~km}^{2}$, with a catchment area of approximately $36500 \mathrm{~km}^{2}$. Its maximum length is $68 \mathrm{~km}$ and the maximum width is $56 \mathrm{~km}$. The mean depth is approximately $1.9 \mathrm{~m}$ and the mean residence time is approximately 309 days. The hydrology and nutrient inputs to Lake Taihu result in a trophic gradient characterized by hypertrophic status in the northern region and mesotrophic status in the southeastern region of the lake (Qin, 2008).

In this study, we collected samples at 18 stations representing three different habitat conditions (Table 1). Stations NB1 to NB6 are located in two north bays (Meiliang Bay and Zhushan Bay) that contain high concentrations of nitrogen and phosphorus from domestic and agricultural discharge. These two bays (hereafter 


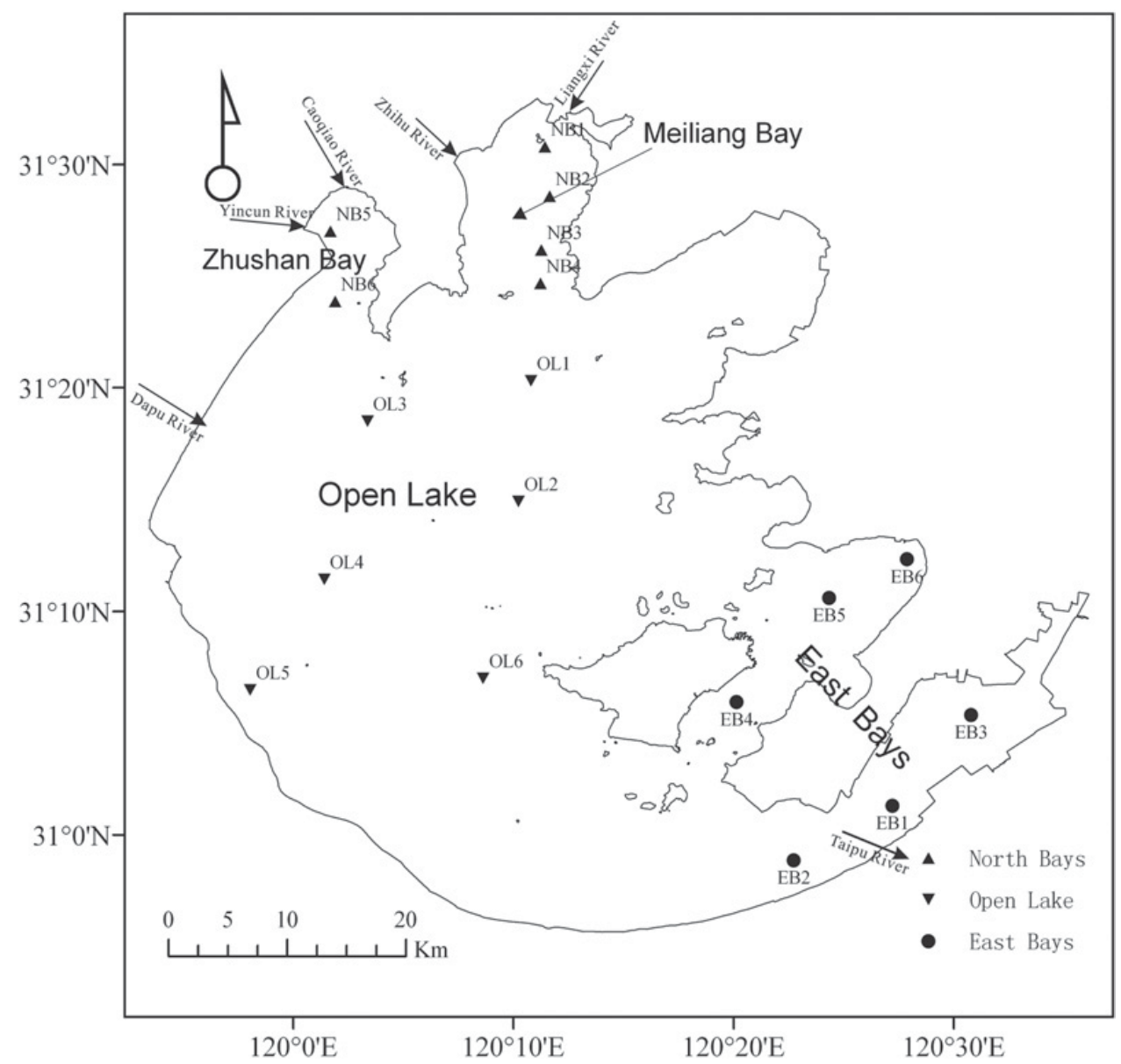

Fig. 1. Location of the benthic macroinvertebrate sampling stations for the three habitats in Lake Taihu.

called North Bays) are subject to severe seasonal algal blooms during summer and autumn and are dominated by Microcystis spp. North Bays are covered with soft sediments $(>20 \mathrm{~cm})$ that present a high nutrient load (James et al., 2009). Stations OL1 to OL6 are located in the open lake, where the water is less enriched in nutrients. This habitat is underlain by a thin layer of muddy sand sediment containing lower nutrient levels (James et al., 2009) and is exposed to intensive windinduced resuspension. The third habitat (stations EB1 to EB6) is located in East Bays that are characterized by clear water and relatively low phytoplankton concentrations and abundant aquatic macrophytes (mainly Potamogeton spp., Vallisneria natanus, Nymphoides peltatum, Hydrilla verticillata, and Trapa incise) (Qin et al., 2007).

\section{Macroinvertebrates sampling}

Benthic samples were collected quarterly at the 18 stations (Fig. 1) from February 2009 to November 2009. Samples were collected using a $0.025 \mathrm{~m}^{2}$ modified Peterson grab, with two grabs comprising a sample, and were pre-sieved in situ through a $250 \mu \mathrm{m}$ mesh size sieve. In the laboratory, the samples were sorted on a white tray and the animals preserved in $7 \%$ buffered formalin solution.
Specimens were identified to the lowest taxonomic level possible, counted, blotted dry and weighed to determine wet weight with an electronic balance (Sartorius BS-124, readability: $0.1 \mathrm{mg}$ ). Mollusca were weighed with their exoskeleton. The identification and classification of macroinvertebrates were mainly based on Liu et al. (1979), Morse et al. (1994) and Wang (2002). Species were divided into five functional feeding groups (gatherers, filterers, scrapers, shredders and predators) according to their food source and feeding mechanism (Liu et al., 1979; Morse et al., 1994; Liu, 2006).

\section{Measurement of environmental parameters}

Water depth, water temperature, $\mathrm{pH}$, and Secchi depth were measured at each station. Conductivity, dissolved oxygen (DO), chemical oxygen demand $\left(\mathrm{COD}_{\mathrm{Mn}}\right)$, biochemical oxygen demand $\left(\mathrm{BOD}_{5}\right)$, total nitrogen $(\mathrm{TN})$, ammonium $\left(\mathrm{NH}_{4}-\mathrm{N}\right)$, nitrite $\left(\mathrm{NO}_{2}-\mathrm{N}\right)$, nitrate $\left(\mathrm{NO}_{3}-\mathrm{N}\right)$, total phosphorus (TP), orthophosphate $\left(\mathrm{PO}_{4}-\mathrm{P}\right)$, total suspended solids (TSS) and chlorophyll $a(\mathrm{Chl} a)$ in the water column were measured in the laboratory according to standard methods (Jin and Tu, 1990).

In May 2009, an additional sediment sample was collected at each station to determine total nitrogen 
(TNs) and total phosphorus (TPs) in the surficial sediments. TNs and TPs were determined by subsampling approximately $30 \mathrm{mg}$ of the dried sediment from each station, which were ground with a mortar and pestle and weighed. Then $25 \mathrm{~mL}$ of distilled water was added, and the samples were analyzed after thawing, using a combined persulphate digestion, followed by spectrophotometric analysis as for phosphate and nitrate. The oxidationreduction potential (ORP) in the surficial sediments was measured in the field using a METTLER-TOLEDO SG2 Portable Meter. The percentage cover of aquatic macrophytes was estimated visually and scored on a scale (classes: $0,1-25,26-50,51-75,76-100 \%$ covering of the substrate adjacent to the sampling station).

\section{Data analysis}

Prior to analysis, the abundance and biomass data were converted to individuals. $\mathrm{m}^{-2}$ and wet weight g.m ${ }^{-2}$, respectively. In this study, we focused on the spatial variation of the macroinvertebrate community in different habitats. Therefore, we averaged the biological and environmental data across the four seasons. Simple descriptors of community structure were calculated, including Shannon-Wiener species diversity and Pielou evenness indices, the abundance and biomass of total macroinvertebrates and four common taxonomic groups (Tubificidae, Bivalvia, Gastropoda and Chironomidae). The relative contribution of the five functional feeding groups was evaluated in terms of abundance. In our study, large unionids (Anodonta woodiana woodiana and Lamprotula leai) and the highly mobile invertebrate (Palaemon modestus) were excluded when calculating abundance and biomass. Differences of these descriptors and environmental parameters among habitats were tested by one-way ANOVA following a post hoc Tukey test. When necessary, data were $\log (x+1)$ transformed and standardized $($ Mean $=0, \mathrm{SD}=1)$ to improve normality and homoscedasticity. ANOVA analyses were performed using the SPSS 13.0 statistical package.

To examine variation in community structure among habitats, multivariate statistical analyses were performed using PRIMER 5.0 (Clarke and Warwick, 2001). Macroinvertebrate community structure was compared between the three habitats using analysis of similarities (ANOSIM) (Clarke, 1993) and non-metric multidimensional scaling (NMDS) on a Bray-Curtis similarity matrix obtained from $\log (x+1)$-transformed invertebrate abundance data. Pairwise comparisons were conducted if the global test statistic $R$ was significant at $P<0.05$ (Clarke, 1993). Similarity percentage (SIMPER) procedures (Clarke, 1993) were also applied to determine the characteristic species for each habitat.

A canonical correspondence analysis (CCA) was carried out using CANOCO 4.5 software (ter Braak and Śmilauer, 2002) to elucidate the relationships between the macroinvertebrate community composition and environmental parameters. A prior detrended correspondence analysis (DCA) analysis revealed that a unimodal model (CCA) would be more appropriate for the dataset (DCA axis 1 st length $=2.58)$. The abundance data and environmental variables (except $\mathrm{pH})$ were $\log (x+1)$ transformed. Water depth was excluded in the CCA analysis because it cannot affect benthic fauna substantially in very shallow lakes. Water temperature, which showed no significant differences among the habitats, was also removed. Manual forward selection was used to determine which environmental variables were significantly related to the benthic community (Monte Carlo test with 499 permutations, $P<0.05)$. The statistical significance of speciesenvironment correlations for the ordination axes were also determined based on 499 Monte Carlo permutation tests. In all the multivariate analyses, rare species occurring at less than 3 of the 18 sampling stations were excluded (15 species were excluded).

\section{Results}

\section{Physicochemical and biological characteristics}

One-way ANOVA analyses indicated that the three habitats had markedly different physicochemical and biological characteristics (Table 1). Generally, North Bays had the highest nutrient loads (e.g., nitrogen and phosphorus in the water column and surficial sediment) and pollution levels (e.g., conductivity, $\mathrm{COD}_{\mathrm{Mn}}$ and $\mathrm{BOD}_{5}$ ). In contrast, East Bays presented the highest Secchi depths and the lowest nutrient loads in the water column. The open lake had the highest values of TSS and ORP, but the lowest values of TNs and TPs, indicating intensive windinduced disturbance in this area. Only East Bays were covered by aquatic macrophytes. According to the fixed boundary classification system for lake trophic status accepted by OECD (1982), the trophic status (assessed by mean Chl $a$ ) was highest in North Bays (eutrophichypertrophic), followed by the open lake (eutrophic) and was lowest in East Bays (mesotrophic-eutrophic).

\section{Abundance, biomass and diversity}

In the 72 quantitative samples collected between February and November 2009, a total of 36 taxa were recorded, including 9 Oligochaeta, 5 Bivalvia, 7 Gastropoda, 10 Chironomidae and 5 other miscellaneous species (Appendix 1, available online at www.limnology-journal.org). Abundance, biomass, diversity (Shannon-Wiener index) and evenness (Pielou index) were used as descriptors of community structure. One-way ANOVA indicated that the "habitats" factor strongly affected these descriptors.

The total abundance of macroinvertebrates ranged from 215 ind. ${ }^{-2}$ at station EB2 to 4467 ind.m ${ }^{-2}$ at station NB5 and was significantly different among the habitats (Fig. 2). In general, Tubificidae, Bivalvia and Gastropoda were the dominant taxa in the three habitats 


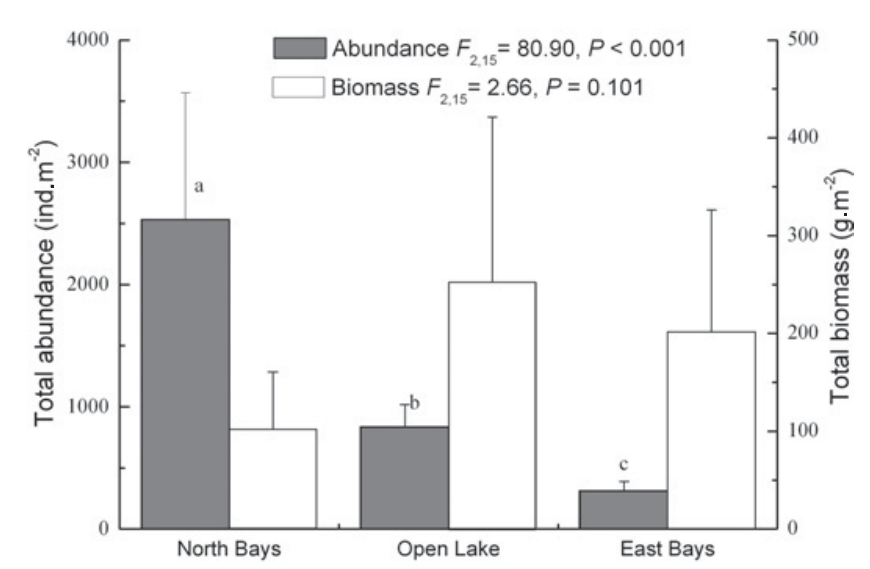

Fig. 2. Total abundance (+1 SD) and biomass (+1 SD) of benthic macroinvertebrates for the three habitats; means with different letters are significantly different as determined by multiple comparisons (one-way ANOVA, post hoc Tukey test, $P<0.05$ ).

(Fig. 3). However, in the open lake, Gammarus sp. and Polychaeta species also contributed to a considerable proportion of the total abundance. Concerning the abundance of the four common taxonomic groups, a significantly higher abundance of Tubificidae was observed in North Bays compared with the open lake and East Bays (Fig. 4) and accounted for $41.7 \%$ to $86.3 \%$ of the total abundance (Fig. 3). In contrast, Bivalvia showed the highest abundance in the open lake and accounted for $18.2 \%$ to $69.3 \%$ of the total abundance. In East Bays, the total abundance was dominated by Gastropoda (50.1-84.6\% of the total abundance), which presented the highest abundance in this habitat. Tubificidae were also important contributors to the total abundance in East Bays (2.8-49.4\% of the total abundance). Chironomidae, however, only accounted for a small proportion of the total abundance in all habitats $(0-22.1 \%$ of the total abundance) and had the highest abundance in North Bays, followed by East Bays and nearly no individuals were found in the open lake (Fig. 4).

In contrast to abundance, the total biomass of macroinvertebrates did not exhibit significant differences among habitats (Fig. 2). Generally, the total biomass was dominated by Bivalvia and Gastropoda due to their relatively large body sizes. Though they were of relatively small sizes, Tubificidae contributed to a considerable proportion of the total biomass in North Bays (Fig. 3).

Assigning individuals to their feeding groups, gatherers always represented a relatively high proportion of the total abundance, especially in North Bays (Fig. 5). Filterers contributed a large proportion to the total abundance in the open lake. Scrapers mainly dominated in East Bays. Predators and shredders only accounted for small percentages of the total abundance in all habitats.

The Shannon-Wiener diversity was highest in East Bays (1.79), followed by North Bays (1.43) and the open lake (1.33), although the differences among these habitats was not found to be significant (Fig. 6). However, the Pielou evenness showed significant differences among habitats. East Bays showed significantly higher evenness compared with North Bays.

\section{Multivariate analyses}

NMDS showed that the three habitats had distinctive communities (Fig. 7), with a low stress value (0.11). Oneway ANOSIM analyses also indicated that the benthic community differed significantly among all habitats (Table 2). The SIMPER procedures indicated that North Bays were mainly characterized by species of Tubificidae (i.e., L. hoffmeisteri, R. sinicus and B. sowerbyi) and Chironomidae (i.e., T. chinensis and $C$. semireductus) (Table 3). Gammarus sp. and C. fluminea were also important species for North Bays. In the open lake, benthic assemblages were characterized by five species belonging to several taxonomic groups (e.g., C. fluminea, L. hoffmeisteri and Gammarus sp.). In contrast, East Bays was mainly characterized by gastropods. It's of note that many species (e.g., L. hoffmeisteri and B. sowerbyi, $C$. fluminea) characterized two or more habitats. However, the abundance of these species varied greatly among habitats (Table 3, Appendix 1), implying that the differences in the benthic community between habitats mainly resulted from differences in the abundance of the taxa for each habitat.

The variations of the benthic community were first tested by several simple CCA models, with each factor as an explanatory variable. Most of the environmental variables (except $\mathrm{pH}$ ) showed significant marginal effects that explained $11.0-27.8 \%$ of the total variation. In the forward selection procedure, many variables were excluded because of their high collinearity and low conditional effects. The CCA finally identified six environmental variables that were highly correlated with the macroinvertebrate community (Fig. 8). The first two axes had eigenvalues of 0.419 and 0.271 , respectively, collectively explaining $49.6 \%$ of the variance in species data and $72.5 \%$ of the variance in the species-environment relationship. The third axis only explained $6.8 \%$ of the species variance. Monte Carlo permutation tests revealed significant species-environment correlations for the first two axes $(P=0.002)$ but not for the third axis $(P=0.224)$. Macroinvertebrate assemblages in East Bays showed a high positive correlation with aquatic macrophytes. In North Bays, benthic communities were highly correlated with three variables that may represent the trophic status (TP and $\mathrm{Chl} a$ ) and pollution level $\left(\mathrm{BOD}_{5}\right)$. Benthic communities in the open lake showed a high correlation with TSS and ORP, which reflected the high intensity disturbance in this area.

\section{Discussion}

The aims of this study were to investigate the community structure of benthic macroinvertebrates in different habitats of Lake Taihu and to discuss the possible mechanisms 

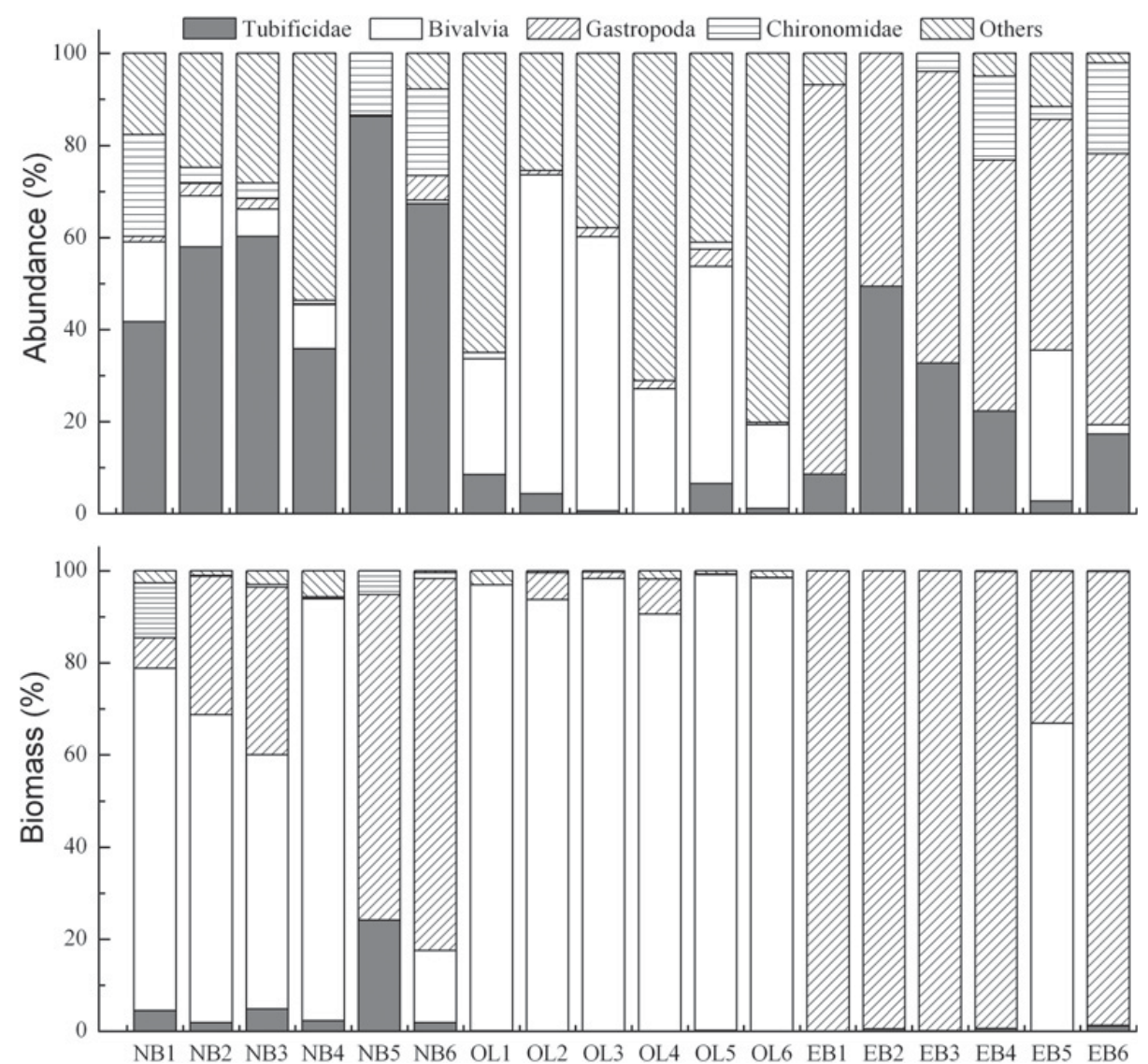

Fig. 3. Relative abundance and biomass of the four common taxonomic groups in the 18 sampling stations for the three habitats.

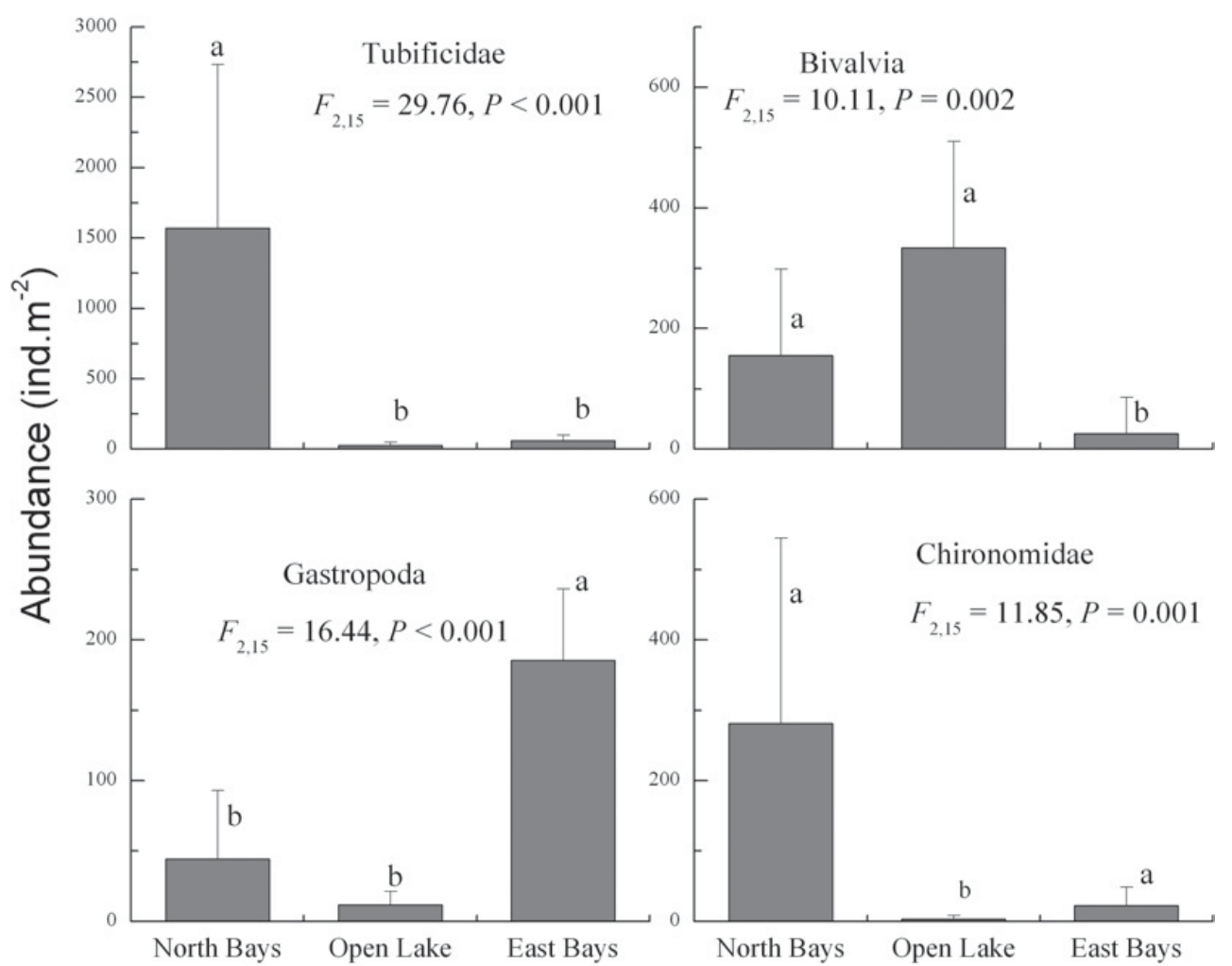

Fig. 4. Comparison of mean abundance $(+1 \mathrm{SD})$ of the four common taxonomic groups among habitats; means with different letters are significantly different as determined by multiple comparisons (one-way ANOVA, post hoc Tukey test, $P<0.05$ ). 


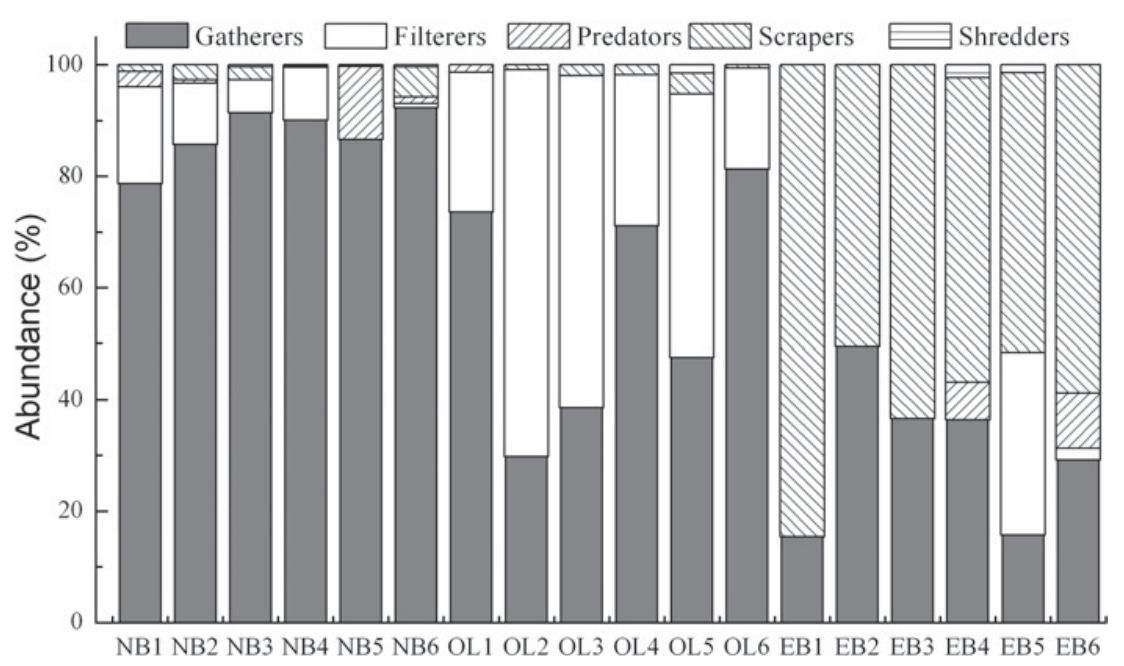

Fig. 5. Relative abundance (\%) of the five functional feeding groups in the 18 sampling stations for the three habitats.

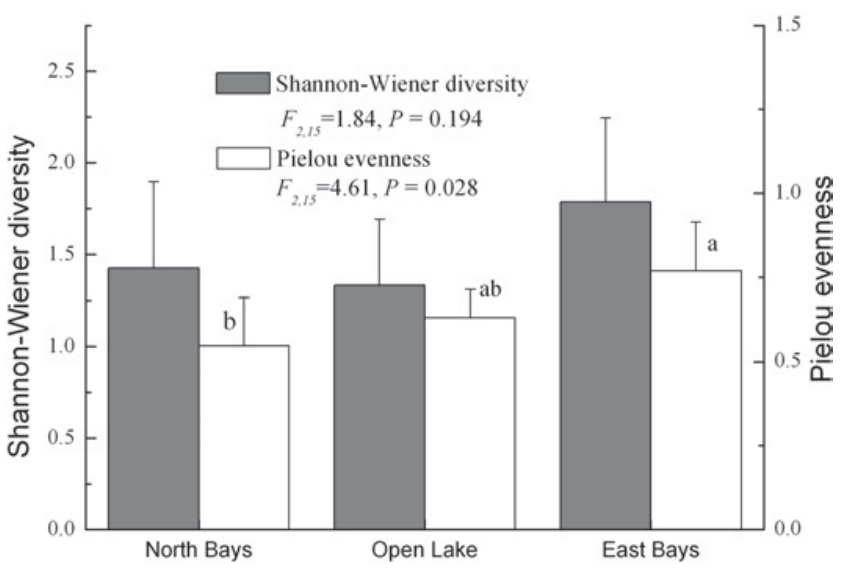

Fig. 6. Shannon-Wiener diversity index (+1 SD) and Pielou evenness index $(+1 \mathrm{SD})$ of the macroinvertebrate communities for the three habitats; means with different letters are significantly different as determined by multiple comparisons (one-way ANOVA, post hoc Tukey test, $P<0.05$ ).

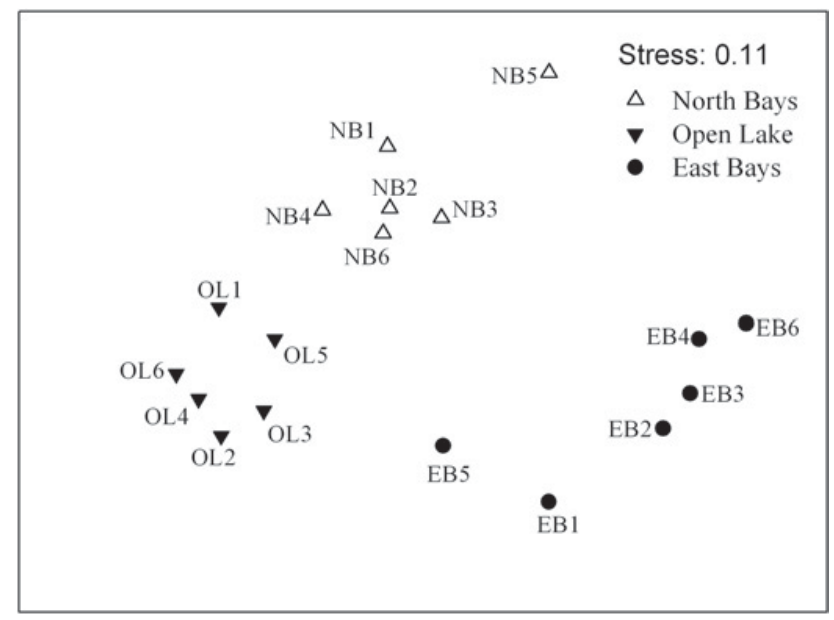

Fig. 7. Non-metric multidimensional scaling (NMDS) of macroinvertebrate communities based on Bray-Curtis similarity coefficients, showing the spatial changes in community structure.
Table 2. One-way analysis of similarities (ANOSIM), showing significant differences in macroinvertebrate assemblages among habitats.

\begin{tabular}{lccc}
\hline Pairwise comparison & $\begin{array}{c}\text { Dissimilarity } \\
(\%)\end{array}$ & $R$ value & $P$ value \\
\hline North Bays $v s$. Open Lake & 69.34 & 0.904 & 0.002 \\
North Bays $v$ s. East Bays & 77.90 & 0.996 & 0.002 \\
Open Lake $v s$. East Bays & 80.98 & 0.929 & 0.002 \\
\hline
\end{tabular}

regulating their structure, diversity and distribution. Our results indicated that benthic communities differed significantly across habitats that exhibited markedly different environmental conditions.

Macroinvertebrate assemblages in North Bays were characterized by the highest abundance of Tubificidae and a lower abundance of Gastropoda and Bivalvia. In the CCA analysis, benthic communities in North Bays showed high positive correlations with three variables that reflected the trophic status and pollution level. In fact, North Bays are the most eutrophic region in Lake Taihu and have endured a long period of eutrophication since the 1960s (Qin et al., 2007; Wu et al., 2007). In Lake Taihu, the major P inputs have been observed to occur in the western and northern lake areas, and about $65 \%$ of the total $\mathrm{P}$ accumulated in the lake (Kelderman et al., 2005). In addition, the inputs of $\mathrm{N}$ and other pollutants (e.g., metal and POPs) were also high from domestic and agricultural wastewater discharged from the rivers (Gao et al., 2005; Wang et al., 2007; Wu et al., 2010). The major impact of eutrophication is the occurrence of algal blooms, with periodic floating mats of Microcystis blooms being observed in summer. However, a large proportion of algae cannot transfer to higher trophic levels because of their low food quality and inedibility (Kainz et al., 2004), resulting in a high accumulation of phytoplankton in the water column. Large amounts of phytoplankton can get deposited on the lake bottom sediments and significantly affect the microhabitat of the water-sediment interface 
Table 3. The results of similarity percentage (SIMPER) analyses. For each habitat, the mean abundance (ind. $\mathrm{m}^{-2}$ ) of characteristic species and their contribution (\%) to within-group similarity were calculated until the cumulative percentage reached $80 \%$.

\begin{tabular}{|c|c|c|c|c|c|c|}
\hline \multirow[b]{2}{*}{ Taxa } & \multicolumn{2}{|c|}{ North Bays } & \multicolumn{2}{|c|}{ Open Lake } & \multicolumn{2}{|c|}{ East Bays } \\
\hline & $\overline{\text { Abun. }}$ & Contr. & Abun. & Contr. & Abun. & Contr. \\
\hline \multicolumn{7}{|l|}{ Tubificidae } \\
\hline Branchiura sowerbyi & 52 & 7.55 & & & 18 & 9.88 \\
\hline Limnodrilus hoffmeisteri & 1368 & 23.77 & 20 & 8.41 & 34 & 12.90 \\
\hline Rhyacodrilus sinicus & 125 & 14.58 & & & & \\
\hline \multicolumn{7}{|l|}{ Bivalvia } \\
\hline Corbicula fluminea & 107 & 8.74 & 330 & 28.33 & & \\
\hline \multicolumn{7}{|l|}{ Gastropoda } \\
\hline Alocinma longicornis & & & & & 34 & 20.91 \\
\hline Bellamya aeruginosa & & & & & 100 & 28.40 \\
\hline Parafossarulus striatulus & & & & & 10 & 6.22 \\
\hline Radix swinhoei & & & & & 6 & 5.65 \\
\hline \multicolumn{7}{|l|}{ Chironomidae } \\
\hline Chironomus semireductus & 127 & 8.76 & & & & \\
\hline Tanypus chinensis & 113 & 6.05 & & & & \\
\hline \multicolumn{7}{|l|}{ Miscellaneous others } \\
\hline Amphipoda sp. & & & 36 & 10.66 & & \\
\hline Gammarus sp. & 464 & 12.26 & 139 & 13.46 & & \\
\hline Polychatea sp. & & & 245 & 23.75 & & \\
\hline Total & 2356 & 81.71 & 771 & 84.61 & 202 & 83.96 \\
\hline
\end{tabular}

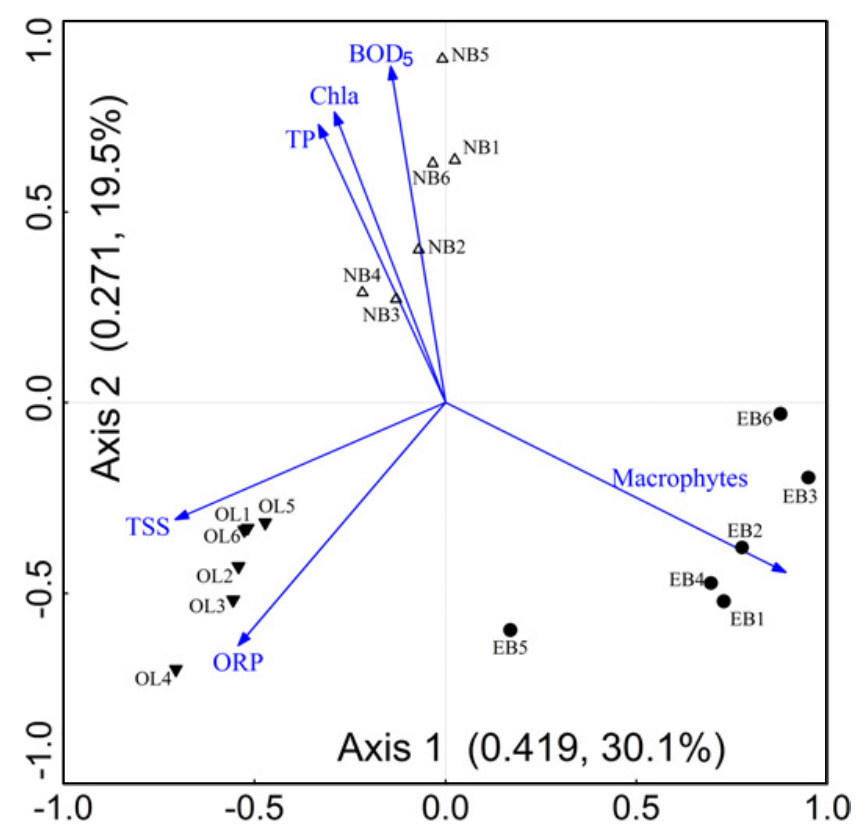

Fig. 8. Canonical correspondence analysis (CCA) biplot showing macroinvertebrate communities in relation to environmental parameters. See Table 1 for environmental variable abbreviations.

(Anderson et al., 2002). The decomposition of algae can significantly decrease or deplete the oxygen content (illustrated by the lowest ORP in the surficial sediment). The low oxygen content will strongly influence the survival of some benthic fauna (e.g., reducing the anti-predation behaviors and survivorship of $C$. fluminea) (Johnson and McMahon, 1998; Saloom and Duncan, 2005). Furthermore, a large population of toxin-producing cyanobacteria can produce a high concentration of Cyanotoxin (mainly Microcystins in Lake Taihu) (Song et al., 2007). Previous studies have found dissolved Microcystins in the entire water column throughout the year in Meiliang Bay, with especially high values in summer (maximum: $6.69 \mu \mathrm{g} . \mathrm{L}^{-1}$ ). B. aerugionsa, a popular food in China, was observed to accumulate a high concentration of Microcystins that was several times higher than the WHO guideline value (Song et al., 2007). Gérard et al. (2009) found that the relative abundance of prosobranchs, pulmonates and bivalves decreased significantly after cyanobacterial blooms. Gérard et al. (2009) also found that bivalves were more sensitive to cyanobacterial bloom than pulmonates. Correspondingly, Oberholster et al. (2009) observed that an increase in Microcystis toxicity at sites dominated by cyanobacterial scum was accompanied by an increase in the total abundance of Hirudinae, Chironomidae, and Tubificidae. From 1998 to 2007, algal blooms in Lake Taihu occurred at increasing frequency and with lengthened duration. An extremely long duration of algal blooms was detected throughout the year of 2007 with the exception of January and February (Duan et al., 2009). Therefore, the frequent long-term cyanobacterial blooms may have a seriously adverse impact on some Mollusca while have little negative effect on Chironomidae and Tubificidae. On the other hand, the relatively weak water current and long residence time in the north basin promoted the sedimentation of organic matter from algal blooms and river inputs, resulting in the fine grain size of sediments in this area. Despite the lack of granulometric analysis of sediments, 
we noticed that there were few size fractions retained in the $250 \mu \mathrm{m}$ sieve in North Bays, indicating its finer sediments (Fig. S1A, available online). Previous studies have demonstrated that species of Tubificidae prefer living in silt-clay and fine sand sediments (Anlauf and Moffitt, 2008) and selectively feed on finer particles less than $63 \mu \mathrm{m}$ in diameter (Rodriguez et al., 2001; Anlauf and Moffitt, 2008). In contrast, fine sediment can significantly reduce the survivorship of gastropods and bivalves by limiting their feeding behaviors (Donohue and Irvine, 2003; Schmidlin and Baur, 2007). Hence, the severe environment in the North Bays may favor the Chironomidae and Tubificidae but inhibit the Mollusca. Our results are in accordance with the model developed by Pearson and Rosenberg (1978), which predicts a decline of suspension feeders and an increase of deposit feeders as organic input to a habitat increases.

Benthic communities in the open lake were mainly dominated and characterized by suspension feeders (mainly C. fluminea). Conversely, very few Tubificidae and nearly no individuals of the Chironomidae were collected in this habitat. The substrate type in the open lake was muddy sand (Fig. S1B, available online), which was a result of wind-induced disturbance (Qin, 2008). Sediment resuspension is the most typical feature in the open lake due to the large wind fetch over the water. The monsoon climate of the Lake Taihu area is characterized by prevailing southeasterly winds in summer and northwesterly winds in winter. Moderate wind (about $4.0 \mathrm{~m} . \mathrm{s}^{-1}$ ) can cause strong mixing of the water column and surficial sediment, which occurs two-thirds of a year in the open lake (Qin, 2008). The frequent, intensive and long duration wind disturbance likely has a significant influence on the benthic communities. It is very difficult for fine organic particles and algae to get deposited and accumulate in this area (James et al., 2009). This would limit the food resources for deposit feeders, but not for suspension feeders. In our study, sampling stations in the open lake showed the lowest $\mathrm{N}$ and $\mathrm{P}$ levels in the surficial sediments, reflecting relatively low nutrient levels. In addition, the large particles retained in the sediment may be difficult to be fed upon by Tubificidae and Chironomidae (Rodriguez et al., 2001). Furthermore, the intensive wind can cause water currents to occur, which may remove these small body size species. In fact, we observed that the benthic assemblages in the open lake were mostly comprised of large-size species and some actively swimming species (e.g., crustaceans). Moreover, the large area of the open lake also reduced the local pool of potential colonists (McCabe and Gotelli, 2000). The extremely intensive disturbance also reduced the diversity of benthic communities in the open lake, which is consistent with the intermediate disturbance hypothesis (IDH) (Townsend and Scarsbrook, 1997).

Our study confirmed the positive effect of macrophytes on benthic communities. Macrophytes were highly correlated with the first CCA axis and discriminated the East Bays from other habitats. In fact, the East Bays were the only habitat covered by dense aquatic macrophytes in our study (Fig. S1C, available online) and presented the highest diversity and evenness of the macroinvertebrate community. Several previous studies have demonstrated the positive effects of macrophytes on diversity and evenness. Generally, the more diversified substrates provided by macrophytes contain more ecological niches than homogeneous systems, which can allow more species to coexist. An artificial plant experiment demonstrated that architectural complexity increases the abundance and diversity of invertebrates, independent of habitat area (Taniguchi et al., 2003). Macrophyte beds also offer refuges against predation by fish and other macroinvertebrates (Padial et al., 2009). In addition, macrophytes provide more surface area for attachment by periphytons, which are a major component in the diet of macroinvertebrate primary consumers. The periphytons growing on macrophytes represent a high-quality food source for gastropods compared with the macrophytes themselves (Jones et al., 1999). Gastropods characterized the East Bays, and very few individuals were collected in the other habitats. Our results are in accordance with the snail-macrophyteepiphyte mutualistic hypothesis (Underwood et al., 1992), which considers that gastropods use macrophytes as habitat because of the associated food availability.

In summary, the results of this study suggest that macroinvertebrate community structure can be highly variable among habitats (e.g., phytoplankton- and macrophyte-dominated habitat) in Lake Taihu. Clear relationships between assemblage structure and environmental variables were documented by multivariate analyses. Trophic status, pollution level, macrophyte distributions and wind exposure were the most important factors regulating the macroinvertebrate assemblages in Lake Taihu. Our study is one of the few that has demonstrated the distinct influence of wind-induced disturbance on macroinvertebrate assemblages in shallow lakes. Our results also suggest that the macroinvertebrate community in the north end of Lake Taihu was dominated by pollution-tolerant taxa, which is likely a result of longterm eutrophication. These results will assist lake management by providing a better understanding of the potential impacts of anthropogenic pollution, such as increased nutrient loadings of water and sediments and equilibria shifts in stable states, on macroinvertebrate assemblages. If lake restoration activities are successful, a less pollutiontolerant and more diverse macroinvertebrate community would be established.

Acknowledgements. The authors thank the Taihu Laboratory for Lake Ecosystem Research (TLLER), Nanjing Institute of Geography and Limnology, Chinese Academy of Science, for providing the water quality data. We also acknowledge Dr Lu Zhang for providing the physicochemical parameters of sediment. This study was funded by the key projects of National Sciences and Foundation of China (Grant No. 40730529), National Basic Research Program of China (No. 2008CB418103) and the project of NSFC (Grant No. 31070418). Finally, we are grateful to the two anonymous reviewers for their constructive comments and helpful suggestions. 


\section{References}

Anderson D.M., Glibert P.M. and Burkholder J.M., 2002. Harmful algal blooms and eutrophication: Nutrient sources, composition, and consequences. Estuar. Coast., 25, 704-726.

Anlauf K.J. and Moffitt C.M., 2008. Models of stream habitat characteristics associated with tubificid populations in an intermountain watershed. Hydrobiologia, 603, 147-158.

Bazzanti M., Della Bella V. and Grezzi F., 2009. Functional characteristics of macroinvertebrate communities in Mediterranean ponds (Central Italy): Influence of water permanence and mesohabitat type. Ann. Limnol. - Int. J. Lim., 45, 29-39.

Céréghino R., Ruggiero A., Marty P. and Angélibert S., 2008. Influence of vegetation cover on the biological traits of pond invertebrate communities. Ann. Limnol. - Int. J. Lim., 44, 267-274.

Chen Y.W., Fan C.X., Teubner K. and Dokulil M., 2003. Changes of nutrients and phytoplankton chlorophyll- $a$ in a large shallow lake, Taihu, China: an 8-year investigation. Hydrobiologia, 506-509, 273-279.

Clarke K.R., 1993. Non-parametric multivariate analyses of changes in community structure. Austral Ecol., 18, 117-143.

Clarke K.R. and Warwick R.M., 2001. Changes in marine communities: an approach to statistical analysis and interpretation, 2nd edition, PRIMER-E, Plymouth.

Covich A.P., Palmer M.A. and Crowl T.A., 1999. The role of benthic invertebrate species in freshwater ecosystemsZoobenthic species influence energy flows and nutrient cycling. BioScience, 49, 119-127.

Donohue I. and Irvine K., 2003. Effects of sediment particle size composition on survivorship of benthic invertebrates from Lake Tanganyika, Africa. Arch. Hydrobiol., 157, 131-144.

Duan H.T., Ma R.H., Xu X.F., Kong F.X., Zhang S.X., Kong W.J., Hao J.Y. and Shang L.L., 2009. Two-decade reconstruction of algal blooms in China's Lake Taihu. Environ. Sci. Technol., 43, 3522-3528.

Dudgeon D., Arthington A.H., Gessner M.O., Kawabata Z.I., Knowler D.J., Lévêque C., Naiman R.J., Prieur-Richard A.H., Soto D. and Stiassny M.L.J., 2005. Freshwater biodiversity: importance, threats, status and conservation challenges. Biol. Rev., 81, 163-182.

Free G., Solimini A.G., Rossaro B., Marziali L., Giacchini R., Paracchini B., Ghiani M., Vaccaro S., Gawlik B.M., Fresner R., Santner G., Schönhuber M. and Cardoso A.C., 2009. Modelling lake macroinvertebrate species in the shallow sublittoral: relative roles of habitat, lake morphology, aquatic chemistry and sediment composition. Hydrobiologia, 633, 123-136.

Gao H.J., Jiang X., Wang F., Bian Y.R., Wang D.Z., Dend J.C. and Yan D.Y., 2005. Residual levels and new inputs of chlorinated POPs in agricultural soils from Taihu Lake region. Pedosphere, 15, 301-309.

Gérard C., Poullain V., Lance E., Acou A., Brient L. and Carpentier A., 2009. Influence of toxic cyanobacteria on community structure and microcystin accumulation of freshwater molluscs. Environ. Pollut., 157, 609-617.

Havens K.E., Jin K.R., Iricanin N. and James R.T., 2007. Phosphorus dynamics at multiple time scales in the pelagic zone of a large shallow lake in Florida, USA. Hydrobiologia, $581,25-42$.
James R.T., Havens K., Zhu G.W. and Qin B.Q., 2009. Comparative analysis of nutrients, chlorophyll and transparency in two large shallow lakes (Lake Taihu, P.R. China and Lake Okeechobee, USA). Hydrobiologia, 627, 211-231.

Jin X.C. and Tu Q.Y., 1990. The standard methods for observation and analysis of lake eutrophication, 2nd edition, China Environmental Science Press, Beijing (in Chinese).

Johnson P.D. and McMahon R.F., 1998. Effects of temperature and chronic hypoxia on survivorship of the zebra mussel (Dreissena polymorpha) and Asian clam (Corbicula fluminea). Can. J. Fish. Aquat. Sci., 55, 1564-1572.

Jones J.I., Young J.O., Haynes G.M., Moss B., Eaton J.W. and Hardwick K.J., 1999. Do submerged aquatic plants influence their periphyton to enhance the growth and reproduction of invertebrate mutualists? Oecologia, 120, 463-474.

Kainz M., Arts M.T. and Mazumder A., 2004. Essential fatty acids in the planktonic food web and their ecological role for higher trophic levels. Limnol. Oceanogr., 49, 1784-1793.

Ke Z.X., Xie P. and Guo L.G., 2008. Controlling factors of spring-summer phytoplankton succession in Lake Taihu (Meiliang Bay, China). Hydrobiologia, 607, 41-49.

Kelderman P., Zhu W. and Maessen M., 2005. Water and mass budgets for estimating phosphorus sediment-water exchange in Lake Taihu (China P. R.). Hydrobiologia, 544, $167-175$.

Liu X.Q., 2006. Food Composition and Food Webs of Zoobenthos in Yangtze Lakes, Ph.D. Dissertation, Institute of Hydrobiology, Chinese Academy of Sciences, Wuhan, P.R. China (in Chinese with English abstract).

Liu Y.Y., Zhang W.Z., Wang Y.X. and Wang E.Y., 1979. Economic Fauna of China: Freshwater Mollusca, Science Press, Beijing (in Chinese).

McCabe D.J. and Gotelli N.J., 2000. Effects of disturbance frequency, intensity, and area on assemblages of stream macroinvertebrates. Oecologia, 124, 270-279.

Morse J.C., Yang L.F. and Tian L.X., 1994. Aquatic insects of China useful for monitoring water quality, Hohai University Press, Nanjing.

Oberholster P.J., Botha A.M. and Ashton P.J., 2009. The influence of a toxic cyanobacterial bloom and water hydrology on algal populations and macroinvertebrate abundance in the upper littoral zone of Lake Krugersdrift, South Africa. Ecotoxicology, 18, 34-46.

OECD (Organization for Economic Cooperation and Development), 1982. Eutrophication of waters, Monitoring assessment and control, Paris.

Padial A.A., Thomaz S.M. and Agostinho A.A., 2009. Effects of structural heterogeneity provided by the floating macrophyte Eichhornia azurea on the predation efficiency and habitat use of the small Neotropical fish Moenkhausia sanctaefilomenae. Hydrobiologia, 624, 161-170.

Palmer M.A., Covich A.P., Lake S., Biro P., Brooks J.J., Cole J., Dahm C., Gibert J., Goedkoop W., Martens K., Verhoeven J. and Van De Bund W.J., 2000. Linkages between aquatic sediment biota and life above sediments as potential drivers of biodiversity and ecological processes. BioScience, 50, 1062-1075.

Pearson T.H. and Rosenberg R., 1978. Macrobenthic succession in relation to organic enrichment and pollution of the marine environment. Oceanogr. Mar. Biol. Ann. Rev., 16, 229-311.

Qin B.Q., 2008. Lake Taihu, China: Dynamics and Environmental Change, Springer, Netherlands. 
Qin B.Q., Xu P.Z., Wu Q.L., Luo L.C. and Zhang Y.L., 2007. Environmental issues of Lake Taihu, China. Hydrobiologia, 581, 3-14.

Ricciardi A. and Rasmussen J.B., 1999. Extinction rates of North American freshwater fauna. Conserv. Biol., 13, 1220 1222.

Rodriguez P., Martinez-Madrid M., Arrate J.A. and Navarro E., 2001. Selective feeding by the aquatic oligochaete Tubifex tubifex (Tubificidae, Clitellata). Hydrobiologia, 463, 133-140.

Saloom M.E. and Duncan R.S., 2005. Low dissolved oxygen levels reduce anti-predation behaviours of the freshwater clam Corbicula fluminea. Freshwat. Biol., 50, 1233-1238.

Sauter G. and Güde H., 1996. Influence of grain size on the distribution of tubificid oligochaete species. Hydrobiologia, 334, 97-101.

Scheffer M., 1998. Ecology of shallow lakes, Springer, Netherlands.

Schmidlin S. and Baur B., 2007. Distribution and substrate preference of the invasive clam Corbicula fluminea in the river Rhine in the region of Basel (Switzerland, Germany, France). Aquat. Sci., 69, 153-161.

Shostell J.M. and Williams B.S., 2007. Habitat complexity as a determinate of benthic macroinvertebrate community structure in cypress tree reservoirs. Hydrobiologia, 575, 389-399.

Smith V.H., Joye S.B. and Howarth R.W., 2006. Eutrophication of freshwater and marine ecosystems. Limnol. Oceanogr., 51, 351-355.

Song L.R., Chen W., Peng L., Wan N., Gan N.Q. and Zhang X.M., 2007. Distribution and bioaccumulation of microcystins in water columns: A systematic investigation into the environmental fate and the risks associated with microcystins in Meiliang Bay, Lake Taihu. Water Res., 41, 2853-2864.

Strayer D., 2006. Challenges for freshwater invertebrate conservation. J. N. Am. Benthol. Soc., 25, 271-287.

Tang X.M., Gao G., Chao J.Y., Wang X.D., Zhu G.W. and Qin B.Q., 2010. Dynamics of organic-aggregate-associated bacterial communities and related environmental factors in Lake Taihu, a large eutrophic shallow lake in China. Limnol. Oceanogr., 55, 469-480.

Taniguchi H., Nakano S. and Tokeshi M., 2003. Influences of habitat complexity on the diversity and abundance of epiphytic invertebrates on plants. Freshwat. Biol., 48, 718-728.

ter Braak C.J.F. and Šmilauer P., 2002. CANOCO Reference manual and CanoDraw for Windows User's guide: Software for Canonical Community Ordination (version 4.5), Microcomputer Power Ithaca, New York.

Townsend C.R. and Scarsbrook M.R., 1997. The intermediate disturbance hypothesis, refugia, and biodiversity in streams. Limnol. Oceanogr., 42, 938-949.

Underwood G.J.C., Thomas J.D. and Baker J.H., 1992. An experimental investigation of interactions in snailmacrophyte-epiphyte systems. Oecologia, 91, 587-595.

Vanni M.J., 2002. Nutrient cycling by animals in freshwater ecosystems. Annu. Rev. Ecol. Syst., 33, 341-370.

Vaughn C.C. and Hakenkamp C.C., 2001. The functional role of burrowing bivalves in freshwater ecosystems. Freshwat. Biol., 46, 1431-1446.

Wang H.Z., 2002. Studies on Taxonomy, Distribution and Ecology of Microdrile Oligochaetes of China, with Descriptions of Two New Species from the Vicinity of the Great Wall Station of China, Antarctica, Higher Education Press, Beijing (in Chinese).

Wang H., Wang C.X., Wu W.Z., Mo Z. and Wang Z.J., 2003. Persistent organic pollutants in water and surface sediments of Taihu Lake, China and risk assessment. Chemosphere, 50, 557-562.

Wang X.L., Lu Y.L., Han J.Y., He G.Z. and Wang T.Y., 2007. Identification of anthropogenic influences on water quality of rivers in Taihu watershed. J. Environ. Sci. (China), 19, 475481.

Wu J.L., Huang C.M., Zeng H.A., Schleser G.H. and Battarbee R., 2007. Sedimentary evidence for recent eutrophication in the northern basin of Lake Taihu, China: human impacts on a large shallow lake. J. Paleolimnol., 38, 13-23.

Wu Y.H., Liu E.F., Yao S.C., Zhu Y.X. and Xia W.L., 2010. Recent heavy metal accumulation in Dongjiu and Xijiu lakes, East China. J. Paleolimnol., 43, 385-392.

Żbikowski J. and Kobak J., 2007. Factors influencing taxonomic composition and abundance of macrozoobenthos in extralittoral zone of shallow eutrophic lakes. Hydrobiologia, 584, 145-155. 